\title{
MENAKAR DERAJAT KEPASTIAN HUKUM DALAM PEMILU PADA UNDANG-UNDANG NOMOR 7 TAHUN 2017
}

\author{
Henri Wijaya \\ Universitas Airlangga \\ henri.wijaya-2019@fisip.unair.ac.id
}

Received: 5 January 2020 | Reviewed: 28 January 2020 | Accepted: 4 February 2020

\begin{abstract}
ABSTRAK
Pelaksanaan Pemilu yang berdasarkan pada norma hukum, akan memberikan kepastian pada seluruh pihak yang terkait dalam pemilu, sehingga peserta pemilu dan masyarakat memiliki kepercayaan terhadap penyelenggara pemilu untuk dapat menjaga tegaknya demokrasi. Kepastian hukum dalam sebuah penyelenggaraan Pemilu dapat menciptakan suatu keadilan bagi semua pihak, terutama peserta pemilu, hal tersebut dapat terwujud dengan adanya pengaturan yang efektif dalam penyelesaian segala permasalahan pemilu yang tertuang dalam sebuah hukum pemilu. Menjadi dasar dari sebuah pesta demokrasi yang serentak dilaksanakan pada tahun 2019, UU Pemilu Nomor 7/2017 yang merupakan penggabungan 3 (tiga) undang-undang yang mengatur tentang pemilihan legislative, pemilihan presiden dan penyelenggara pemilu, ternyata memiliki derajat kepastian hukum pada pelaksanaan Pemilihan Umum yang belum optimal dan perlu mendapat perbaikan dibeberapa pasal. Meski aspek-aspek Pemilu telah tertuang pada pasal-pasal dalam UU Pemilu Nomor 7/2017, namun masih terdapat ketentuan-ketentuan yang tidak konsisten dalam beberapa pasal, pasal yang multitafsir, pasal yang sulit dilaksanakan di lapangan dan adanya temuan terkait pasal-pasal yang rawan untuk digugat di Mahkamah Konstitusi
\end{abstract}

Kata Kunci: Undang-Undang Nomor 7 Tahun 2017, Kepastian Hukum, Pemilu

Korespondensi:

Universitas Airlangga

Jl. Airlangga No.4 - 6, Airlangga

Surabaya, Jawa Timur

E-mail: henri.wijaya-2019@fisip.unair.ac.id JURNAL ILMIAH DINAMIKA SOSIAL 4 (1) 2020|82 


\begin{abstract}
Election implementation which is based on legal norms, will provide certainty to all parties involved in the election, so that election participants and the public have trust in the electoral management body, to maintain the enforcement of democracy. The elections law must regulate the mechanism and resolution of legal issues for more effectively of the election implementation, this aims to provide a legal certainty in the implementation of elections, so that justice for all parties can be fulfilled. As the basis for the implementation of the 2019 Elections, Law Number 7 of 2017 which is a merging of 3 (three) laws : legislative elections, presidential elections and the electoral management body, apparently has a degree of legal certainty in the general election that is not optimal yet and needs to be improved in several articles. Although aspects of the General Election are contained in the articles in Law Number 7 of 2017, there are still inconsistent provisions in several articles, multiple interpretations, articles that are difficult to implement in the field and the articles which prone to be sued in the Constitutional Court
\end{abstract}

Keywords: Law Number 7 of 2017, Legal Certainty, Elections

\title{
PENDAHULUAN
}

Teori demokrasi konstitusional tidak dapat dipisahkan dari konsep demokrasi dan nomokrasi, karena kedua konsep tersebut saling melengkapi sehingga memunculkan konsep negara demokrasi yang berdasarkan hukum atau yang disebut sebagai negara demokrasi konstitusional. Konsep Negara demokrasi konstitusional terwujud dari adanya Undang-Undang yang mengatur pelaksanaan Pemilu yang menjelaskan perihal konsepkonsep Pemilu yang demokratik dan mengandung kepastian hukum.

Sebuah Pemilu yang demokratik dirumuskan dengan Predictable Procedures But Unpredictable Results, yang memiliki makna bahwa pemilu merupakan prosedur konversi suara pemilih menjadi kursi yang diatur dengan perundang-undangan yang mengandung kepastian hukum (Surbakti, 2016). Pelaksanaan Pemilu yang berdasarkan pada norma hukum, akan memberikan kepastian pada seluruh pihak yang terkait dalam pemilu, sehingga peserta pemilu dan masyarakat memiliki kepercayaan terhadap penyelenggara pemilu untuk dapat menjaga tegaknya demokrasi. Kepastian hukum dalam sebuah penyelenggaraan Pemilu dapat menciptakan suatu keadilan bagi semua pihak, terutama peserta pemilu, hal tersebut dapat terwujud dengan adanya pengaturan yang efektif dalam penyelesaian segala permasalahan pemilu yang tertuang dalam sebuah hukum pemilu. 
Prinsip-prinsip penyusunan Undang-Undang Pemilu, antara lain:

1. Undang-undang pemilu harus mematuhi prinsip-prinsip dasar pemilu, seperti kerahasiaan kertas suara.

2. Undang-undang pemilu harus memberikan kekuasaan bagi badan pelaksana pemilu dan harus menyatakan secara jelas dan menguraikan cakupan dan sampai sejauh mana kekuasaan badan itu untuk mengeluarkan perintah.

3. Undang-undang pemilu harus memberikan suatu proses yang dengannya peserta pemilu dan pemilih dapat menyampaikan pengaduan dan banding yang timbul dari pengadopsian dan pelaksanaan perintah badan pelaksana pemilu. Proses ini juga harus memungkinkan pengaduan dan banding itu diselesaikan tepat waktu dan efisien.

4. Undang-undang pemilu harus menyatakan hierarki hukum secara jelas, termasuk preseden dari ketentuan konstitusional dan legislatif atas perintah badan pelaksana pemilu.

5. Undang-undang pemilu harus menyatakan dan menguraikan secara jelas kekuasaan tetap badan pelaksana pemilu (“kekuasaan intrinsik"- nya) untuk mengeluarkan perintah dalam keadaan darurat, termasuk pada hari pemilihan, untuk menghadapi setiap keadaan yang tidak diantisipasi.(International IDEA, 2002, p. 19-20)

Adanya sebuah hukum yang secara khusus mengatur tentang Pemilu dan kepastian hukum dalam sebuah pelaksanaan Pemilu menjadi sesuatu yang sangat penting karena hal-hal sebagai berikut:

1. Pemilu merupakan proses perebutan kursi kekuasaan sebagai penyelenggara Negara yang cenderung ketat dan rentan terjadi kekerasan dalam proses tersebut. Guna mencegah hal-hal negative yang muncul dari proses persaingan tersebut, perlu adanya hukum pemilu untuk menjamin keadilan bagi peserta pemilu. Proses inilah yang seringkali disebut dengan pelembagaan konflik politik.

2. Kepastian hukum pada pelaksanaan Pemilihan Umum diperlukan untuk menjamin agar seluruh pihak terkait pada pelaksanaan Pemilu memiliki pemahaman yang sama mengenai ‘aturan main' atau prosedur Pemilu tetapi juga untuk menjamin KPU yang independen. Yang dimaksud dengan KPU 
yang independen adalah KPU yang menyelenggarakan Pemilu tidak berdasarkan tekanan ataupun intervensi kekuatan lain melainkan menyelenggarakan pemilihan umum semata-mata berdasarkan peraturan perundang-undangan yang dipahami sama oleh semua pihak.

3. Pemilu sebagai upaya untuk mengubah suara pemilih menjadi kursi akan dapat berlangsung secara demokratik (Pemilu Demokratik) bila Delapan Paramater Pemilu Demokratik (yang dirumuskan berdasarkan empat prinsip Pemilu Demokratik) dapat dijabarkan secara operasional dalam UU Pemilu. Kepastian hukum dalam proses penyelenggaraan Pemilu berdasarkan hukum Pemilu itulah yang dimaksud dengan predictable procedures.

4. Penyelesaian sengketa, penegakan hukum serta partisipasi politik akan terjamin bila seluruhnya tertuang dalam UU Pemilu. (Surbakti et al, 2015, p.11-12)

Sejarah menunjukkan bahwa Indonesia telah berulang kali melaksanakan Pemilu dan Pemilihan Kepala Daerah. Setiap pemilihan umum maupun pemilihan kepala daerah dilaksanakan berdasarkan Undang-Undang. Berikut ini pemilihan umum dan pemilihan kepala daerah yang pernah dilaksanakan di Indonesia berdasarkan Undang-Undang yang digunakan sebagai dasar pemilihan tersebut dilaksanakan, yaitu:

1. UU Nomor 7/1953 Tentang Pemilihan Anggota Konstituante dan Anggota DPR.

Undang-undang ini digunakan sebagai dasar pelaksanaan Pemilihan Umum pada Tahun 1955, yaitu untuk memilih legislative tingkat Pusat, Prov dan Kab/Kota dan anggota Konstituante Republik Indonesia. Pemilihan umum yang pertama ini menganut sistem pemilihan umum proposional murni, dengan stelsel daftar dan dengan kemungkinan para pemilih memilih seorang calon tertentu.

2. UU Nomor 15/1969 Tentang Pemilu Anggota Badan Permusyawaratan / Perwakilan Rakyat.

Undang-undang ini digunakan sebagai dasar pelaksanaan Pemilihan Umum pada Tahun 1971, yaitu untuk memilih legislative tingkat Pusat, Prov dan Kab/Kota. Pemilu ini menganut sistem pemilihan umum proporsional.

3. UU Nomor 4/1975 Tentang Perubahan UU No.15/1969 tentang Pemilu Anggota Badan Permusyawaratan / Perwakilan Rakyat 
Undang-undang ini digunakan sebagai dasar pelaksanaan Pemilihan Umum pada Tahun 1977, yaitu untuk memilih legislative tingkat Pusat, Prov dan $\mathrm{Kab} /$ Kota.

4. UU Nomor 2/1980 Tentang Perubahan UU No. 15/1969 tentang Pemilu Anggota Badan Permusyawaratan/ Perwakilan Rakyat sebagaimana telah diubah dengan UU No. 4/1975

Undang-undang ini digunakan sebagai dasar pelaksanaan Pemilihan Umum pada Tahun 1982, yaitu untuk memilih legislative tingkat Pusat, Prov dan Kab/Kota.

5. UU Nomor 1/1985 tentang Perubahan UU No.15/1969 tentang Pemilu Anggota Badan Permusyawaratan/ Perwakilan Rakyat yang diubah dengan UU No. 4/1975 dan UU No. 2/1980.

Undang-undang ini digunakan sebagai dasar pelaksanaan Pemilihan Umum pada Tahun 1987, 1992 dan 1997untuk memilih legislative tingkat Pusat, Prov dan Kab/Kota.

6. UU No. 3/1999 Tentang Pemilu.

Undang-undang ini digunakan sebagai dasar pelaksanaan Pemilihan Umum pada Tahun 1999 untuk memilih legislative tingkat Pusat, Prov dan Kab/Kota.

7. Pasca Pemilihan Umum Tahun 1999 terdapat 3 Pemilihan yaitu:

a. Pemilu Legislatif, yaitu:

- UU No.12/2003 tentang pemilu Anggota DPR, DPD, dan DPRD, sebagai dasar pelaksanaan Pemilihan Legislatif tahun 2004

- UU No.10/2008 tentang pemilu Anggota DPR, DPD, dan DPRD, sebagai dasar pelaksanaan Pemilihan Legislatif tahun 2009

- UU No.8/2012 tentang pemilu Anggota DPR, DPD, dan DPRD, sebagai dasar pelaksanaan Pemilihan Legislatif tahun 2014

b. Pemilu Presiden dan Wakil Presiden, yaitu:

- UU No.23/2003 Tentang Pemilu Presiden \& Wakil Presiden, sebagai dasar pelaksanaan Pilpres tahun 2004

- UU No.42/2008 Tentang Pemilu Presiden dan Wakil Presiden, sebagai dasar pelaksanaan Pilpres tahun 2009 dan 2014 
c. Pemilihan Kepala Daerah

Pemilihan Kepala Daerah di Kutai Kartanegara, Kaltim, pada juni 2005 merupakan pilkada yang dilaksanakan untuk pertama kalinya di Indonesia, yang selanjutnya dilaksanakan hampir setiap tahun di berbagai daerah di seluruh Indonesia sesuai dengan masa jabatan kepala daerah yang bersangkutan berakhir, dan baru di tahun 2015 mulai dilaksanakan pilkada serentak yang dilanjutkan di tahun 2017 dan 2018. Undang-Undang yang digunakan antara lain:

- UU No.32/2004 Tentang Pemda.

- UU No.12/2008 Tentang Perubahan Atas UU No.32/2004 Tentang Pemda.

- UU No.1/2015 tentang Penetapan Perppu No.1/2014 tentang Pilkada Menjadi UU.

- UU No.8/2015 Tentang Perubahan UU No.1/2015 tentang Penetapan Perppu No.1/2014 tentang Pilkada Menjadi UU.

- UU No.10/2016 Tentang Perubahan Kedua UU No.1/2015 tentang Penetapan Perppu No.1/2014 tentang Pilkada Menjadi UU.

8. UU No.7/2017 Tentang Pemilu.

Undang-Undang ini digunakan sebagai dasar pelaksanaan Pemilu 2019 yang dilaksanakan serentak untuk memilih Presiden dan Wakil Presiden, Anggota DPR RI, DPRD Prov, DPD dan DPRD Kab/Kota di seluruh Indonesia.

Dalam pidatonya di Surabaya, 20 November 2016, yang berjudul Tata Kelola Pemilu Sebagai Subkajian Pemilu Terapan, Prof. Ramlan Surbakti, Drs., MA.,Ph.D, menyampaikan bahwa Pemilu sebagai prosedur yang diatur dengan kepastian hukum berarti:

1. Semua aspek Pemilu diatur secara lengkap, tanpa adanya kekosongan hukum

2. Tidak terdapat ketentuan yang saling bertentangan

3. Tidak ada ketentuan yang multitafsir

4. Semua ketentuan dapat dilaksanakan dalam praktek.

Menjadi dasar dari sebuah pesta demokrasi yang serentak dilaksanakan pada tahun 2019, UU Pemilu Nomor 7/2017 merupakan penggabungan 3 (tiga) undang-undang yang mengatur tentang pemilihan legislative, pemilihan presiden dan penyelenggara 
pemilu. Hal tersebut dilakukan dengan tujuan bahwa diperlukan pengaturan pemilihan umum sebagai perwujudan sistem ketatanegaraan yang demokratis dan berintegritas demi menjamin konsistensi dan kepastian hukum serta pemilihan umum yang efektif dan efisien. (UU 7/2017, poin Menimbanghuruf b). Dari fenomena tersebut penulis tertarik untuk meneliti dan menganalisis lebih lanjut terhadap derajat kepastian hukum dalam pelaksanaan Pemilihan Umum padaUU Pemilu No.7/2017, dengan beberapa rumusan masalah, yaitu:

1. Apakah semua aspek Pemilu telah diatur secara lengkap?

2. Apakah terdapat ketentuan yang saling bertentangan?

3. Apakah ada ketentuan yang multitafsir?

4. Apakah semua ketentuan dapat dilaksanakan dalam praktek?

\section{METODE PENELITIAN}

Fokus penelitian ini adalah menganalisis derajat kepastian hukum dalam pelaksanaan Pemilihan Umum pada UU Pemilu No.7/2017, untuk mencapainya maka poin-poin yang dianalisis dalam undang-undang tersebut berdasarkan prinsip-prinsip kepastian hukum dalam pemilu, yang pernah disampaikan Prof. Ramlan Surbakti, Drs., MA.,Ph.D di Surabaya, 20 November 2016, yang berjudul Tata Kelola Pemilu Sebagai Subkajian Pemilu Terapan.

Metode yang digunakan adalah studi kepustakaan, dimana sumber-sumber kepustakaan digunakan untuk menyusun kerangka penelitian, alat untuk menganalisis sekaligus untuk memperoleh data. Adapun literature yang digunakan dalam penelitian ini yaitu UU Pemilu No.7/2017, sebagai sumber utama, sedangkan sumber kedua meliputi seluruh literatur selain UU Pemilu No.7/2017 yang berkaitan dengan kepastian hukum dalam Pemilu baik berupa artikel, maupun undang-undang terdahulu. Pengumpulan data hingga proses analisis dilaksanakan mulai November 2019. 


\section{PEMBAHASAN}

\section{A. Aspek-aspek Pemilihan Umum dalam UU Pemilu No.7/2017}

Dalam Undang-Undang Pemilu, dalam hal ini UU Pemilu No.7/2017, diatur berbagai aspek yang berkaitan dengan pemilihan umum. Adapun aspek-aspek pemilu yang dijabarkan dalam UU Pemilu No.7/2017, yaitu:

1. Asas dan Prinsip Penyelenggaraan Pemilu

Sesuai dengan UU Pemilu No.7/2017 pasal 2, pemilu diselenggarakan dengan asas:
a. Langsung
b. Umum
c. Bebas
d. Rahasia
e. Jujur
f. Adil

Sedangkan prinsip-prinsip yang digunakan dalam penyelenggaraan pemilu yaitu:
a. Mandiri
b. Jujur
c. Adil
d. Berkepastian hukum
e. Tertib
f. Terbuka
g. Proporsional
h. Professional
i. Akuntabel
j. Efektif
k. Efisien

2. Pendaftaran Pemilih

Sesuai UU Pemilu No.7/2017 pasal 198 ayat 1, yang memiliki hak untuk memilih dalam Pemilu adalah WNI pada saat pemungutan suara telah berusia 17 tahun atau lebih, sudah menikah atau pernah menikah. Sedangkan sesuai pasal 200, TNI/Polri tidak menggunakan haknya untuk memilih. 
Dalam penyusunan daftar pemilih, sebagaimana tertuang dalam Bab V hal-hal yang diatur adalah sebagai berikut: Data kependudukan, Daftar Pemilih, Pemutakhiran data pemilih, Penyusunan DPS, Penyusunan DPT, Penyusunan Daftar Pemilih Bagi Pemilih LN, Penetapan DPT, Pengawasan dan Penyelesaian Perselisihan pada pelaksanaan updating data dan rekapitulasi DPT.

3. Peserta Pemilu dan Pencalonan

Dalam Buku Ketiga Bab II UU Pemilu No.7/2017, hal-hal yang diatur tentang Peserta dan Persyaratan Mengikuti Pemilu, antara lain:

a. Persyaratan terkait Calon Presiden dan Calon Wakil Presiden, tertuang dalam pasal 169 hingga 171

b. Peserta Pemilihan Umum Legislatif, diatur dalam hal:

> Persyaratan Partai Politik Menjadi Peserta Pemilu, tertuang dalam pasal 172 yang menjelaskan bahwa peserta dalam pelaksanaan Pemilu Legislatif adalah parpol. Dan selanjutnya diperjelas dengan ketentuanketentuan yang dijabarkan pada pasal 173 hingga 175.

$>$ Pendaftaran Partai Politik Sebagai Peserta Pemilu, tertuang dalam pasal 176 hingga 177

> Verifikasi Partai Politik Calon Peserta Pemilu, tertuang dalam pasal 178

Penetapan Partai Politik Sebagai Peserta Pemilu, tertuang dalam pasal 179

> Pengawasan Atas Pelaksanaan Verifikasi Partai Politik Calon Peserta Pemilu, tertuang dalam pasal 180

c. Peserta Pemilu DPD, hal-hal yang diatur antara lain:

> Peserta dalam penyelenggaran Pemilu DPD adalah perseorangan, tertuang dalam pasal 181

Persyaratan menjadi Peserta dalam Pemilu DPD, tertuang dalam pasal 182

d. Ketentuan Saat Pendaftaran Bagi Calon Peserta Pemilu Yang Kepengurusan Partai Politiknya Terjadi Perselisihan, diatur dalam pasal 184 
Sedangkan hal-hal yang diatur dalam penyampaian usulan Bakal Capres dan Cawapres serta Penetapan Pasangan Capres dan Cawapres dan Pencalonan Anggota DPR, DPD, DPRD Prov dan DPRD Kab/Kota tertuang dalam BAB VI, yaitu

a. Tata Cara Penentuan, Pengusulan dan Penetapan Pasangan Calon, antara lain mengatur tentang:

Proses Penentuan Pasangan Calon

- Pengusulan Capres dan Cawapres oleh Parpol atau Gabungan Parpol, dilakukan dalam 1 (satu) pasangan, tertuang dalam pasal 221.

- Pengusulan Capres dan Cawapres oleh Parpol atau Gabungan Parpol yang memperoleh kursi lebih dari 20\% dari jumlah kursi yang ada di DPR atau mendapat 25\% suara sah nasional dari Pileg sebelumnya, hal ini tertuang dalam pasal 222

Tata cara proses pendaftaran bagi bakal pasangan Capres dan Cawapres, tertuang dalam pasal 226 hingga pasal 229.

> Verifikasi Bakal Pasangan Calon, tertuang dalam pasal 230 hingga 234

$>$ Penetapan dan Pengumuman Pasangan Calon, tertuang dalam pasal 235 hingga 238

> Pengawasan atas Verifikasi Kelengkapan Adminitrasi Pasangan Calon, tertuang dalam pasal 239

b. Proses pendaftaran bagi calon Anggota DPR, DPD, DPRD Prov dan DPRD Kab/Kota, antara lain:

Dalam pasal 240, tertuang syarat-syarat yang dibutuhkan bagi WNI yang ingin mendaftar sebagai bakal calon anggota DPR RI, Prov dan $\mathrm{Kab} /$ Kota.

Dalam pasal 241 hingga 247, dijabarkan tentang proses teknis parpol dalam mengajukan bakal calon anggota DPR Pusat, Prov dan Kab/Kota, yaitu dengan beberapa poin sebagaimana berikut:

- Proses penyeleksian bakal calon DPR Pusat, Prov dan Kab/Kota dilakukan oleh parpol selaku peserta dalam pelaksanaan Pemilu Legislatif. 
- Dalam proses penyeleksian bakal calon DPR Pusat, Prov dan $\mathrm{Kab} / \mathrm{Kota}$, parpol tidak diperkenankan untuk memperoleh imbalan.

- $100 \%$ (seratus persen) dari keseluruhan kursi di masing-masing dapil adalah jumlah maksimal pengusulan calon yang termuat dalam Daftar bakal calon.

- $30 \%$ (tiga puluh persen) adalah jumlah minimal calon perempuan yang termuat dalam Daftar bakal calon.

Verifikasi Kelengkapan berkas pendaftaran bakal calon DPR Pusat, Prov dan Kab/Kota, tertuang dalam pasal 248 hingga 250.

Pengawasan atas Verifikasi Kelengkapan berkas pendaftaran bakal calon DPR Pusat, Prov dan Kab/Kota, tertuang dalam pasal 251

$>$ Penyusunan DCS Anggota DPR Pusat, Prov dan Kab/Kota, tertuang dalam pasal 252 hingga 255.

Penetapan dan Pengumuman DCT Anggota DPR Pusat, Prov dan $\mathrm{Kab} /$ Kota, tertuang dalam pasal 256 dan 257.

Teknis pelaksanaan Pendaftaran Bakal Calon Anggota DPD, tertuang dalam pasal 258 .

$>$ Verifikasi Kelengkapan berkas pendaftaran Bakal Calon Anggota DPD, tertuang dalam pasal 259 dan 260.

> Pengawasan Atas Verifikasi Kelengkapan Adminitrasi Bakal Calon Anggota DPD, tertuang dalam pasal 261.

$>$ Penetapan DCS Anggota DPD, tertuang dalam pasal 262 hingga 265.

$>$ Penetapan dan Pengumuman DCT Anggota DPD, tertuang dalam pasal 266.

4. Penyelenggara Pemilu

Penyelenggara Pemilu adalah institusi yang mempunyai fungsi dan tanggung jawab berdasarkan hukum untuk melaksanakan unsur-unsur utama dalam penyelenggaraan Pemilihan Umum.

Sesuai UU Pemilu No.7/2017 pada bagian Buku Kedua Bab I, Bab II dan Bab III, ada 3 (tiga) lembaga Penyelenggara Pemilu, yaitu: 
a. KPU, yang terdiri dari KPU RI di tingkat pusat, KPU Prov, KPU/KIP Kab/Kota, PPK di tingkat kecamatan, PPS di tingkat Desa, KPPS di tingkat TPS dan Pantarlih.

b. Bawaslu, yang terdiri dari Bawaslu RI di Tingkat Pusat, Bawaslu Provinsi, Bawaslu Kabupaten/Kota, Panwascam di tingkat kecamatan, PPL di tingkat desa dan PTPS di tingkat TPS

c. DKPP

DKPP berjumlah 7 (tujuh) orang yang terdiri atas:

$>1$ (satu) orang ex officio dan unsur KPU;

$>1$ (satu) orang ex officio dari unsur Bawaslu; dan

$>5$ (lima) orang tokoh masyarakat.

Presiden mengusulkan 2 (dua) orang sedangkan DPR mengusulkan 3 (tiga) orang untuk mengisi susunan Anggota DKPP dari kategori tokoh masyarakat.

5. Sistem Pemilu

Sistem Pemilu adalah seperangkat prosedur untuk mengkonversi perolehan suara dalam sebuah pemilihan umum menjadi kursi oleh partai pemenang pemilu dan kandidat terpilih. Ada beberapa unsur dalam Sistem Pemilu, yaitu:

a. Besaran Daerah Pemilihan

Sesuai dengan pasal 185 UU Pemilu No.7/2017, Dapil untuk pemilihan anggota legislative disusun dengan memperhatikan prinsip:

Kesetaraan nilai suara

> Ketaatan pada sistem Pemilu yang proporsional

$>$ Proporsionalitas

$>$ Integralitas wilayah

$>$ Berada dalam cakupan wilayah yang sama;

$>$ Kohesivitas

$>$ Kesinambungan

Kursi untuk anggota DPR ditetapkan sebanyak 575 (lima ratus tujuh puluh lima), sedangkan Dapil bagi Pemilu DPR Pusat adalah provinsi, kabupaten/kota, atau gabungan kabupaten/kota. Poin-poin tersebut tertuang dalam pasal 186 dan 187. 
Sebagaimana tertuang dalam pasal 188, kursi yang tersedia bagi DPRD Prov, ditetapkan minimal sejumlah 35 (tiga puluh lima) dan 120 (seratus dua puluh) adalah jumlah maksimal yang diperkenankan. Dapil anggota DPRD Prov adalah sebuah kab/kota atau gabungan dari beberapa kab/kota. Kursi yang disediakan di masing-masing Dapil Anggota DPRD Prov minimal sejumlah (tiga) kursi dan jumlah maksimal yang diperkenankan adalah 12 (dua belas) kursi.

KPU Kab/Kota menetapkan kursi bagi DPRD Kab/Kota dengan jumlah minimal sebanyak 20 (dua puluh) dan paling maksimal yang diperkenankan yaitu sejumlah 55 (lima puluh lima) kursi, dengan daerah pemilihan yaitu sebuah kecamatan atau gabungan dari beberapa kecamatan. Di masing-masing dapil, kursi yang diperkenankan adalah sejumlah 3 (tiga) hingga 12 (dua belas) kursi. Hal tersebut dijabarkan pada pasal 189.

Berdasarkan jumlah kursi di masing-masing daerah pemilihan berdasarkan pasal 186 sampai dengan pasal 190 dalam UU Pemilu No.7/2017 diatas, maka Indonesia menggunakan Multy Member Constituency.

b. Peserta Pemilu dan Pola Pencalonan

Dalam Pilpres, hal-hal yang diatur dalam UU Pemilu No.7/2017, yaitu: Pengusulan capres dan cawapres dijelaskan pada pasal 221.

> Ketentuan parpol atau gabungan parpol yang diperkenankan mengajukan usulan capres dan cawapres dijelaskan dalam pasal 222.

Dalam Pemilu Legislatif, hal-hal yang diatur dalam UU Pemilu No.7/2017, yaitu:

Pasal 172 menjelaskan tentang peserta dalam pemilu legislatif.

> Pasal 173 menjelaskan tentang ketentuan partai politik yang diperkenankan ikut dalam pemilihan umum legislative.

- Daftar bakal calon memuat maksimal 100\% (seratus persen) dari kursi yang disediakan di masing-masing dapil dengan jumlah calon perempuan minimal 30\% (tiga puluh persen)

Dalam Pemilu DPD, hal-hal yang diatur dalam UU Pemilu No.7/2017, yaitu: 
Perseorangan merupakan peserta dalam Pemilu DPD, dengan cara memenuhi persyaratan sebagaimana ketentuan terlebih dahulu.

c. Model Penyuaraan

Pemberian suara untuk Pemilu, sesuai dengan pasal 353, yaitu dilakukan dengan cara:

Dalam Pilpres, pemilih diperkenankan untuk mencoblos nomor, nama, foto paslon, atau logo parpol pengusul dalam satu kotak pada SS yang tersedia;

Dalam Pemilu Legislatif, pemilih diperkenankan untuk mencoblos nomor atau logo parpol, atau nama caleg dalam surat suara yang telah disediakan oleh KPU.

Dalam Pemilu DPD, pemilih diperkenankan mencoblos nomor, nama, atau foto calon dalam surat suara yang telah disediakan oleh KPU di masing-masing TPS.

d. Formula Pemilihan dan Penentuan Calon Yang Menjadi Pemenang Dalam Pemilu

Hal ini berkaitan dengan rumus yang dipakai dalam mengkonversi suara sah untuk menjadi sejumlah kursi bagi parpol di masing-masing dapil serta tata cara penentuan calon yang ditetapkan sebagai yang terpilih di dapildapil tersebut.

Dalam pasal 416, diatur tentang teknis penentuan Pasangan Capres dan Cawapres terpilih dalam Pemilu, yaitu:

Pasangan Capres dan Cawapres terpilih dalam Pemilu adalah yang mendapat 50\% (lima puluh persen) lebih suara dari jumlah suara sah keseluruhan, dengan minimal 20\% (dua puluh persen) suara di masingmasing provinsi yang tersebar di lebih dari $1 / 2$ (setengah) jumlah provinsi di Indonesia.

> Jika tidak ada Pasangan Capres dan Cawapres yang memenuhi criteria di atas maka 2 (dua) Pasangan Capres dan Cawapres yang mendapat suara terbanyak akan dipilih kembali secara langsung dalam Pilpres putaran kedua. 
> Jika tidak ada Pasangan Capres dan Cawapres yang memenuhi criteria pertama diatas karena memiliki jumlah suara yang sama, maka akan dipilih kembali secara langsung dalam Pilpres putaran kedua.

Jika Pasangan Capres dan Cawapres dengan jumlah suara yang sama sejumlah 3 (tiga) Pasangan Calon atau lebih, peringkat pertama dan kedua ditentukan sesuai dengan persebaran wilayah dalam perolehan suara.

Dalam pasal 418, 419 dan 420, Penetapan Perolehan Kursi dan Calon Terpilih Anggota DPR, DPD, dan DPRD, yaitu:

> KPU RI menetapkan kursi yang diperoleh oleh Parpol yang menjadi peserta dalam penyelenggaraan Pemilu DPR Pusat.

KPU Prov menetapkan kursi yang diperoleh oleh Parpol yang menjadi peserta dalam penyelenggaraan Pemilu Legislatif di tingkat provinsi.

KPU Kab/Kota menetapkan kursi yang diperoleh oleh Parpol yang menjadi peserta dalam pelaksanaan pemilu legislative di tingkat kab/kota.

> Hasil rekapitulasi seluruh suara sah dari masing-masing parpol yang memenuhi ketentuan Pasal 414 di daerah pemilihan yang bersangkutan, menjadi dasar penetapan kursi yang diperoleh.

Tata cara penentuan jumlah kursi yang diperoleh masing-masing parpol di setiap dapil, adalah sebagai berikut:

- KPU menetapkan jumlah suara sah masing-masing parpol di setiap dapil.

- KPU membagi suara sah masing-masing parpol dengan bilangan pembagi 1, 3, 5 dan seterusnya.

- Hasil dari proses pembagian diatas, selanjutnya diurut sesuai dengan jumlah terbanyak.

- Parpol yang mendapat hasil pembagian paling banyak pertama akan memperoleh kursi pertama, dan parpol yang mendapat hasil paling banyak kedua akan memperoleh kursi kedua, dan seterusnya hingga tidak ada lagi kursi tersisa untuk dibagikan.

\section{e. Electoral Threshold}

Sesuai dengan pasal 414 UU Pemilu No.7/2017, bahwa 4\% (empat persen) dari keseluruhan suara sah nasional adalah ambang batas jumlah suara 
minimal yang harus dipenuhi oleh parpol agar dapat ikut dalam penentuan kursi parlemen.

f. Kalender Pemilu, sesuai pasal 167 ayat 1, bahwa setiap 5 (lima) tahun, Indonesia melaksanakan pemilihan umum.

6. Proses Penyelenggaraan Tahapan

Sesuai dengan pasal 167 ayat 4UU Pemilu No. 7/2017, tahapan penyelenggaraan Pemilu, meliputi:

a. Penyusunan rencana kegiatan sekaligus kebutuhan anggaran serta PKPU sebagai dasar hukum teknis pelaksanaan pemilu.

b. Updating dan Penyusunan DPT.

c. Pendaftaran dan verifikasi Peserta Pemilu;

d. Penetapan Peserta Pemilu;

e. Penentuan kursi dan daerah pemilihan;

f. Pencalonan Presiden dan Wakil Presiden serta anggota legislatif;

g. Masa Kampanye Pemilu;

h. Masa Tenang;

i. Pemungutan dan Rekapitulasi Suara

j. Penentuan hasil Pemilu; dan

k. Pengucapan sumpah dan janji Presiden dan Wakil Presiden terpilih serta anggota legislative terpilih.

7. Pengawasan, Penegakan Hukum dan Penyelesaian Sengketa

Sesuai dengan pasal 89 ayat 1 bahwa pengawasan penyelenggaraan pemilu dilakukan oleh Bawaslu. Bawaslu bertugas mengawasi seluruh jalannya penyelenggaraan pemilu sekaligus penyelenggara pemilu itu sendiri, yang dilakukan dalam rangka pencegahan terhadap adanya pelanggaran administrasi ataupun pidana pemilu.

Sesuai dengan pasal 1 ayat 38 bahwa terdapat sebuah Gakkumdu adalah sentra dari segala proses upaya penegakan hukum tindak pidana dalam pelaksanaan Pemilihan Umum yang gawangi oleh Bawaslu dan jajarannya, Polri, Polda se-Indonesia, Polres se Indonesia dan Kejaksaan beserta jajarannya yang diperjelas dalam pasal 486. 
Sesuai dengan pasal 93 huruf $\mathrm{b}$, bahwa tugas Bawaslu adalah untuk mencegah dan menindak seluruh proses yang terjadi dalam sengketa pemilu, dan selanjutnya tugas Bawaslu diperjelas kembali dalam pasal 94 ayat 3, yaitu antara lain:

a. Menerima pengajuan penanganan sengketa dalam pelaksanaan Pemilihan Umum.

b. Menguji secara resmipengajuan penanganan sengketa dalam pelaksanaan Pemilihan Umum.

c. Menjadi penengah antara pihak-pihak yang terlibat dalam sengketa.

d. Melaksanakan proses penyelesaian perkara yang berkaitan dengan sengketa dalam pelaksanaan Pemilihan Umum.

e. Memberikan keputusan terkait sengketa proses Pemilu.

Adapun penjelasan tentang pengertian sengketa pemilu, tertuang pada pasal 466 dimana yang dimaksud dengan Sengketa proses Pemilu yaitu sengketa yang terjadi antar parpol ataupun calon/pasangan calon dan sengketa antara parpol ataupun calon/pasangan calon dengan Penyelenggara Pemilu sebagai tindak lanjut adanya keputusan KPU beserta jajarannya.

Kelemahan UU Pemilu No.7/2017 ini adalah dari segi ancaman hukumannya, yang berakibat tidak dapat dilakukan penahanan kepada para pelaku, karena rata-rata diancam dibawah 5 (lima) Tahun, sehingga mempersulit proses penyidikan. (Perbawa, 2019, p. 99-100)

8. Partisipasi Pemilih/Masyarakat

Partisipasi Pemilih/Masyarakat bisa dilakukan dalam berbagai bentuk. Sesuai dengan pasal 448 ayat 2, bahwa partispasi masyarakat dapat dilakukan dengan turut aktif dalam kegiatan sosialisasi tentang tahapan Pemilihan Umum oleh KPU, turut serta dalam proses pendidikan politik bagi Pemilih yang diselenggarakan parpol, ikut dalam proses survei yang terkait dengan pemilihan umum dan ikut membagikan/menyebarluaskan hasil quick count dalam pemilihan umum.

9. Peran TNI, Polri dan Pemerintah

TNI, Polri dan Pemerintah bisa berperan dalam berbagai tahapan pemilu, meski tidak dalam porsi besar sebagai pelaksana pemilu, antara lain: 
a. Dalam hal Kampanye, sebagaimana diatur dalam pasal 306 yaitu terkait peran TNI/Polri dan pemerintah/pemda.

b. Dalam proses distribusi dan pengawalan logistic pemilu, sebagai dijelaskan pada pasal 341 ayat 8

\section{B. Konsistensi ketentuan-ketentuan dalam UU Pemilu No.7/2017}

Sesuai dengan pasal 172, peserta dalam pemilihan umum legislatif adalah partai politik, dimana selanjutnya partai politik menyusun daftar nama calon berdasarkan nomor urut dan minimal terdapat 1 calon wanita di setiap 3 (tiga) orang bakal calon, sebagaimana tertuang pada pasal 246 ayat 1 dan 2. Dan, berdasarkan pasal 422, penentuan calon terpilih anggota legislatif dari parpol yang menjadi peserta dalam penyelenggaran pemilihan umum ditetapkan atas dasar adanya suara terbanyak dari setiap caleg di satu daerah pemilihan yang tercantum pada surat suara.

Pasal-pasal tersebut diatas menunjukkan sebuah ketidak konsistenan ketentuanketentuan antara penyusunan daftar calon dan penetapan calon terpilih. Pada pasal 246 tersebut, seolah-olah menunjukkan bahwa nomor urut calon memberi peran dalam proses penetapan calon terpilih nantinya, akan tetapi, berdasarkan pasal 422, penentuan calon yang terpilih adalah berdasar perolehan suara terbanyak oleh masing-masing caleg.

\section{Perumusan ketentuan-ketentuan secara jelas dan tunggal arti}

Dalam Pasal 1 ayat 35 UU Pemilu No.7/2017, menyebutkan bahwa Kampanye Pemilu adalah suatu kegiatan yang dilakukan oleh parpol/pasangan calon presiden atau pihak lain yang mendapat mandat dari peserta pemilihan umum untuk berupaya meyakinkan pemilih dengan menunjukkan visi, misi, program dan/atau citra diri. Perumusan ketentuan yang kurang jelas dan multitafsir terletak pada poin "citra diri Peserta Pemilu" pada pasal tersebut. Hal ini dikarenakan tidak adanya penjelasan lebih rinci terkait yang dimaksud dengan "citra diri" dalam pasal tersebut, bahkan dalam bagian penjelasan UU Pemilu No.7/2017.

Permasalahan multitafsir muncul ketika Bawaslu menyebut citra diri yang dimaksud adalah nomor dan logo partai, sedangkan menurut Abdul Hakam Naja selaku anggota Komisi Pemerintahan DPR dari fraksi PAN, citra diri tersebut bersifat kumulatif dengan memasukkan seluruh unsur kampanye, mulai dari visi, misi, program sampai dengan logo dan nomor urut partai. Partai Solidaritas Indonesia (PSI) merupakan partai 
yang mendapat teguran Bawaslu terkait tafsir citra diri ini. Dimana kronologinya adalah pada 23 April 2018, PSI memasang iklan di Jawa Pos. Karena dalam iklan tersebut terdapat nomor dan tanda gambar PSI, Bawaslu menilai bahwa PSI telah mencuri start dalam kegiatan kampanye, sebelum jadwal yang telah ditentukan, karena seharusnya kampanye Pemilu 2019 memang baru boleh dilaksanakan terhitung sejak tanggal 23 September 2018. (Siddiq, Mei 26, 2018)

\section{Pelaksanaan ketentuan-ketentuan dalam praktek}

Pada pasal 348 ayat 1, menyebutkan bahwa proses pemungutan suara di setiap TPS di seluruh Indonesia hanya boleh diikuti oleh pemilih dengan kriteria sebagaimana berikut:

1. WNI yang memiliki KTP elektronik dan namanya ada dalam DPT di TPS yang bersangkutan.

2. WNI yang memiliki KTP elektronik dan namanya ada dalam DPTb di TPS yang bersangkutan.

3. WNI yang memiliki KTP elektronik namun namanya tidak ada dalam DPT dan $\mathrm{DPTb}$

4. WNI yang berhak untuk memilih (yang diperjelas dalam pasal 348 ayat 9 yang menyebutkan bahwa WNI yang berhak untuk memilih dapat memilih di TPS, TPSLN dengan menunjukkan KTP elektronik)

Pasal tersebut diatas menjelaskan bahwa pada intinya, yang berhak menggunakan hak pilih saat proses pemungutan suara adalah pemilik KTP elektronik. Ketentuan ini sulit dilaksanakan dilapangan, terutama bagi para pemilih pemula, yaitu para pemilih yang baru berumur 17 (tujuh belas) tahun saat proses pemungutan suara, dimana menurut UU Pemilu No.7/2017 pasal 198, yang bersangkutan telah memiliki hak pilih. Letak kesulitan dalam pelaksanaan dari ketentuan ini adalah, bahwa kategori pemilih semacam ini (berumur 17 (tujuh belas) tahun saat proses pemungutan suara), yaitu yang bersangkutan belum memiliki KTP elektronik meski telah berumur 17 (tujuh belas) tahun saat proses pemungutan suara berlangsung. Tidak dimilikinya KTP elektronik oleh pemilih pemula kategori ini bukan tanpa sebab, karena pada UU Adminduk No.23/2006 pasal 63 ayat 1, bahwa kewajiban untuk memiliki KTP elektronik hanya bagi WNI yang sudah berusia 17 (tujuh belas) tahun atau sudah menikah atau pernah menikah. 


\section{E. Pasal-pasal yang rawan gugatan di Mahkamah Konstitusi}

Selain pasal-pasal yang berkaitan dengan kepastian sekaligus ketidakpastian hukum diatas, penulis menemukan pasal-pasal yang rawan untuk digugat di Mahkamah Konstitusi, antara lain:

1. Pada pasal 2 yang menjelaskan tentang asas pemilu, tidak muncul poin periodik sebagai salah satu asas pemilu. Periodik (5 Tahun sekali) seharusnya masuk ke dalam asas pemilu, bukan hanya dalam hal pelaksanaan saja sebagaimana poin periodik dijelaskan pada pasal 167 yang menyebutkan bahwa setiap 1 (satu) kali dalam 5 (lima) tahun, Indonesia menyelenggarakan Pemilihan Umum. Hal ini dikarenakan periodik tidak sekedar menunjukkan jadwal, kapan pemilu dilaksanakan, melainkan juga menunjukkan adanya masa jabatan bagi setiap kursi yang diperebutkan dalam sebuah pemilu. Dimana dalam masa jabatan tersebut, pemilih dapat meminta pertanggungjawaban dari incumbent sedangkan bagi incumbent, dapat menjelaskan pertanggungjawaban atas jabatan yang telah diemban selama ini.

2. Dalam Pasal 173 ayat 3 yang menyebutkan bahwa Parpol yang lolos verifikasi pada pemilu sebelumnya, tidak perlu dilakukan verifikasi ulang dan langsung menjadi parpol Peserta dalam penyelenggaraan Pemilihan Umum. Pasal tersebut mengakibatkan adanya perlakuan yang berbeda terhadap parpol-parpol yang ikut dalam proses verifikasi. Pasal tersebut (sebagaimana Pasal 8 ayat 1 dalam UU Pileg No.8/2012) juga bertentangan dengan Keputusan Mahkamah Konstitusi dengan No.52/PUU-X/2012, yang telah menjadi putusan inkracht pada saat pelaksanaan Pileg 2014 yang telah membatalkan adanya perbedaan perlakuan dalam proses verifikasi peserta pemilu, dimana menurut MK, hal tersebut tidak sesuai dengan UUD' 45.

3. Pada pasal 228 yang mengatur tentang pemberian dan penerimaan imbalan dalam kegiatan pengajuan calon Presiden dan Wakil Presiden tidak mengatur sanksi pidana terhadap tindakan mahar politik. Satu-satunya sanksi yang dapat dijatuhkan hanya saksi administratif berupa pelarangan mengajukan calon pada periode berikutnya, dan sanksi tersebut hanya berlaku bagi Parpol penerima mahar politik. Padahal secara prinsip mahar politik tentu merupakan suatu tindak pidana yang seharusnya terdapat sanksi pidananya. 
4. Pasal 189 ayat (5) yang menyebutkan bahwa Dapil dan jumlah kursi pada pemilihan anggota DPRD Prov, tercantum dalam Lampiran IV yang merupakan bagian tidak dapat dipisah dari UU Pemilu No.7/2017. Ketentuan ini merupakan kemunduran dari kewenangan KPU. Penataan dapil legislatif seharusnya merupakan wewenang KPU selaku penyelenggara pemilu, bukan wewenang DPR yang kemungkinan besar akan memiliki kepentingan sebagai peserta pemilu. Jika proses penentuan dapil dilakukan oleh KPU, pasti akan ada proses uji publik, yang bisa diikuti oleh semua pihak, baik parpol maupun masyarakat umum. Proses uji publik inilah yang tidak ada ketika dapil pemilihan anggota DPRD Prov ditentukan oleh DPR, sehingga dianggap jauh dari kesan demokratis.

5. Pada pasal 278, 280, 284, 515, dan 523 yang menjelaskan tentang aturan dalam hal pemberian imbalan dengan tujuan mempengaruhi pemilih atau bisa disebut dengan politik uang mengalami kemunduran jika dibandingkan dengan UU No.10/2016 Tentang Perubahan Kedua Atas UU No.1/2015 Tentang Penetapan Perppu No.1/2014 Tentang Pilkada Menjadi Undang-Undang. Pada UU pemilihan kepala daerah tersebut, baik pemberi maupun penerima money politic dapat dihukum pidana, sehingga praktik money politic dapat ditekan. Hal berbeda muncul dalam UU Pemilu No.7/2017, dimana ancaman pidana hanya diberlakukan pada pemberi, tidak pada penerima, hal inilah yang membuat penerima, secara psikologis, tidak akan memiliki rasa takut ketika terlibat dalam praktik money politic tersebut.

\section{KESIMPULAN}

Berdasarkan pembahasan diatas maka dapat diambil simpulan atas rumusan masalah yaitu sebagai berikut:

1. Aspek-aspek Pemilu telah tertuang dalam pasal-pasal yang ada dalam UU Pemilu No.7/2017. Adapun aspek-aspek pemilu tersebut antara lain:
a. Asas dan Prinsip Penyelenggaraan Pemilu
b. Pendaftaran Pemilih
c. Peserta Pemilu dan Pencalonan
d. Penyelenggara Pemilu
e. Sistem Pemilu 
f. Proses Penyelenggaraan Tahapan

g. Pengawasan, Penegakan Hukum dan Penyelesaian Sengketa

h. Partisipasi Pemilih/Masyarakat

i. Peran TNI, Polri dan Pemerintah

2. Terdapat ketentuan-ketentuan yang tidak konsisten dalam beberapa pasal pada UU Pemilu No.7/2017 yaitu pasal 246 dan 422 yang berkaitan dengan proses penyusunan daftar calon dan penetapan calon terpilih.

3. Terdapat pasal yang multitafsir yaitu pada pasal 1 ayat 35 terkait pemahaman pengertian Citra Diri oleh beberapa pihak terkait dalam Pemilu Tahun 2019.

4. Terdapat pasal yang sulit dilaksanakan di lapangan yaitu pasal 348 ayat 1 UU Pemilu No.7/2017 yang tidak sejalan dengan UU Adminduk No.23/2006 pasal 63 ayat 1 terkait kepemilikan KTP elektronik.

5. Terdapat juga pasal-pasal yang rawan untuk digugat di Mahkamah Konstitusi

Berdasarkan poin 2 (dua) hingga poin (5) dari simpulan diatas, menunjukkan bahwa derajat kepastian hukum dalam pelaksanaan Pemilihan Umum pada UU Pemilu No.7/2017 masih belum optimal dan perlu mendapat perbaikan dibeberapa pasal, terutama pasal-pasal yang tidak sesuai dengan prinsip kepastian hukum serta pasal-pasal yang bermasalah dan rawan untuk digugat di Mahkamah Konstitusi. Perbaikan dapat dilakukan atas inisiatif DPR sendiri ataupun sebagai tindak lanjut putusan Mahkamah Konstitusi jika terdapat gugatan terkait pasal-pasal dalam UU Pemilu No.7/2017 yang dimenangkan oleh Mahkamah Kontitusi. 


\section{DAFTAR PUSTAKA}

International Institute for Democracy and Electoral Assistance (International IDEA). (2002).Standar-standar internasional untuk pemilihan umum : Pedoman peninjauan kembali kerangka hukum pemilu Seri buku panduan, Sweden : Bulls Tryckeri

Perbawa, Sukawati Lanang P. (2019). Penegakan hukum dalam pemilihan umum. Jurnal Ilmiah Dinamika Sosial, 3 (1), 99-100

Siddiq, Taufiq. (2018, Mei 26). Komisi II DPR: Poin citra diri di UU pemilu bisa multitafsir. Tempo.Co.https://nasional.tempo.co/read/1092815/komisi-ii-dprpoin-citra-diri-di-uu-pemilu-bisa-multitafsir (Diakses pada 18 Desember 2019)

Surbakti, Ramlan. (2016). Pidato inagurasi anggota baru akademi ilmu pengetahuan indonesia (AIPI), Surabaya : Fakultas Ilmu Sosial dan Ilmu Politik Universitas Airlangga

Surbakti, Ramlan dkk. (2015). Naskah akademik dan draft RUU kitab hukum pemilu: Usulan masyarakat sipil,Jakarta: Kemitraan bagi Pembaruan Tata Pemerintahan di Indonesia

Undang-Undang Nomor 7 Tahun 2017 Tentang Pemilihan Umum

Undang-Undang Nomor 23 Tahun 2006 Tentang Administrasi Kependudukan 